\title{
STRATEGI PENGEMBANGAN DAERAH TERTINGGAL DALAM UPAYA PERCEPATAN PEMBANGUNAN EKONOMI PEDESAAN
}

\author{
Almasdi Syahza dan Suarman \\ Lembaga Penelitian Universitas Riau, Pekanbaru \\ Kampus Bina Widya Km 12,5 Simpang Baru Pekanbaru 28293, Telepon 0761-63266 \\ E-mail: asyahza@yahoo.co.id
}

Diterima 12 Juni 2012 / Disetujui 14 Maret 2013

\begin{abstract}
The implementation of development, especially in coastal areas of Riau Province, has not been able to improve the welfare of the people especially those living in rural areas. The disparity between rural and urban areas caused by bias and distortion of the development which more pro to urban economy. It causes disadvantaged areas that poor and underdeveloped. The strategy of disadvantaged areas development in Regency of Kepulauan Meranti is the development of agriculture sector based on agribusiness, because most of its population are farmers and fishermen. In the effort to spur the development from economic and social aspects in disadvantaged areas, then the program of rural development should prioritize the three main aspects, those are: 1) Improvement of People's Economy (Eradicate Poverty); 2) Improving the Quality of Human Resources (Alleviation of Ignorance); 3) Infrastructure Development.
\end{abstract}

Keywords: disadvantaged village, poverty, rural economy, eradicate poverty

\begin{abstract}
Abstrak: Pelaksanaan pembangunan, khususnya di wilayah pesisir di provinsi Riau belum mampu meningkatkan kesejahteraan masyarakat terutama yang berdiam di daerah pedesaan. Terjadinya kesenjangan antara daerah pedesaan dan perkotaan disebabkan karena bias dan distorsi pembangunan yang lebih banyak berpihak kepada ekonomi perkotaan. Akibatnya timbul daerah-daerah tertinggal yang miskin dan terkebelakang. Strategi pengembangan desa tertinggal di kabupaten Bengkalis adalah pembangunan sektor pertanian berbasis agribisnis, karena sebagian besar penduduknya merupakan petani dan nelayan. Dalam upaya memacu pembangunan dari sisi aspek ekonomi dan sosial di daerah tertinggal, maka program pembangunan pedesaan harus memproritaskan tiga aspek utama, yaitu: 1) Peningkatan Ekonomi Rakyat (Mengentaskan Kemiskinan); 2). Peningkatan Kualitas Sumberdaya Manusia (Kebodohan); 3). Pembangunan Infrastruktur.
\end{abstract}

Kata kunci: desa tertinggal, kemiskinan, ekonomi pedesaan, mengentaskan kemiskinan

\section{PENDAHULUAN}

Pelaksanaan pembangunan di daerah Riau, khususnya di wilayah pesisir belum mampu meningkatkan kesejahteraan masyarakat terutama yang berdiam di daerah pedesaan. Terjadinya kesenjangan antara daerah pedesaan dan perkotaan disebabkan karena bias dan distorsi pembangunan yang lebih banyak berpihak kepada ekonomi perkotaan. Akibatnya timbul daerah-daerah tertinggal yang miskin dan terbelakang.
Salah satu kabupaten yang merasakan ketimpangan dan banyaknya daerah tertinggal di provinsi Riau adalah Kabupaten Kepulauan Meranti. Kabupaten tersebut merupakan pemekaran dari kabupaten induk yakni Kabupaten Bengkalis. Kabupaten Kepulauan Meranti merupakan salah satu kabupaten otonomi baru yang dibentuk berdasarkan Undang-Undang Nomor 2 Tahun 2009. Kabupaten Kepulauan Meranti memiliki 5 (lima) kecamatan dengan luas daerah $3.707 .84 \mathrm{~km}^{2}$. Jumlah penduduk sebanyak 216.329 jiwa. 
Kabupaten Kepulauan Meranti juga berdekatan dengan pengembangan Batam sebagai Kawasan Perdagangan Bebas dan Pelabuhan Bebas (KPBPB) yang diatur melalui Peraturan Pemerintah Nomor 46 tahun 2007 dan bahagian yang tidak terpisahkan dari Free Trade Zone Batam, Bintan dan Karimun (FTZ-BBK). Batam sebagai Free Trade Zone (FTZ) yang sebelumnya telah diamanatkan oleh Undang-Undang Nomor 44 Tahun 2007 tentang Kawasan Perdagangan Bebas dan Pelabuhan Bebas (KPBPB), berubah menjadi suatu usaha untuk mempercepat pengembangan ekonomi di wilayah tertentu yang bersifat strategis bagi pengembangan ekonomi nasional dan untuk menjaga keseimbangan kemajuan suatu daerah dalam kesatuan ekonomi nasional yang dengan Kawasan Ekonomi Khusus (KEK). KEK adalah kawasan dengan batas tertentu dalam wilayah hukum Negara Kesatuan Republik Indonesia yang ditetapkan untuk menyelenggarakan fungsi perekonomian dan memperoleh fasilitas tertentu (Zainal, 2010).

Kedudukan strategis Kabupaten Kepulauan Meranti yang berdekatan dengan Batam sebagai FTZ terhadap Singapura akan memberikan berbagai peluang pengembangan kawasan hinterland Batam, melalui penetapan peran sinergis terhadap pengembangan aktifitas ekonomi dan sosial, baik untuk jangka pendek, jangka menengah maupun jangka panjang. Kawasan hinterland Batam (dalam hal ini wilayah Kabupaten Kepulauan Meranti) dapat memainkan peranannya sebagai extension activity and buffer area. Kabupaten Kepulauan Meranti sebagai salah satu hinterland Batam dapat menjadi key success factor dan stimulator bagi penyelenggaran Kawasan Ekonomi Khusus Batam Bintan dan Karimum (KEK-BBK). Di samping itu dapat pula mentransformasi diri agar memiliki daya saing dalam menangkap berbagai peluang ekonomi KEK-BBK. Pengembangan kawasan Kabupaten Kepulauan Meranti untuk mendukung KEK-BBK harus dicermati sejak dini agar berbagai konsep pengembangan wilayah di Kabupaten Kepulauan Meranti benar-benar fokus dan terstruktur dengan baik.

Dalam upaya menciptakan Kabupaten Kepulauan Meranti sebagai hinterland KEK Batam, diperlukan arah pengembangan antara lain memperkuat fungsi Kabupaten Kepulauan Meranti di bidang pertanian, perkebunan, perikanan, infra struktur, peningkatan sumber daya manusia tempatan, pariwisata, yang kesemuanya itu tentunya haruslah sejalan dengan Rencana Tata Ruang Wilayah Kabupaten Meranti itu sendiri.

Setiap pusat pertumbuhan ekonomi akan mempunyai daerah penarikan dan daerah penolakan sampai batas tertentu, sehingga dalam suatu wilayah yang luas akan terbentuk gugusan-gugusan pusat pertumbuhan ekonomi dengan wilayah pengaruhnya (hinterland) masing-masing. Dalam ilmu ekonomi regional teori pusat pertumbuhan ekonomi dinyatakan sebagai salah satu instrumen pembangunan wilayah yang cukup baik karena dapat menimbulkan beraneka efek atau dampak yang positif terhadap pembangunan wilayah yang ada disekitarnya (Richardson, 2001). Pusat pertumbuhan ekonomi akan menimbulkan efek tetesan ke bawah (trickling down effect atau spread effect) dan efek polarisasi (polarization effect atau backwash effect) pada wilayah yang ada di sekitarnya (hinterland). Pendapatan wilayah akan lebih besar jika investasi pembangunan dikonsentrasikan pada pusat pertumbuhan dibandingkan jika investasi pembangunan yang sama digunakan secara menyebar dalam seluruh wilayah yang bersangkutan.

Tantangan yang dihadapi oleh daerah otonom yang baru khususnya Kabupaten Kepulauan Meranti adalah peningkatan pembangunan daerah dan kemandirian dalam pembangunan dengan kendala ketersediaan sumberdaya di daerah. Dengan demikian penentuan kebijakan dan strategi pembangunan ekonomi yang tepat sangat diperlukan. Arah penentuan kebijakan strategi tersebut adalah tercapainya kriteriakriteria prioritas pembangunan berupa penurunan bentuk-bentuk ketimpangan, kebijakan yang sesuai dengan keinginan masyarakat dan pembangunan yang mampu meningkatkan pertumbuhan daerah. Sedangkan harapan dari pelaksanaan otonomi daerah itu sendiri adalah terciptanya kesejahteraan masyarakat yang semakin meningkat. Dalam kaitan tersebut, salah satu langkah yang perlu dilakukan pemerintah daerah adalah merumuskan kebijakan pembangunan yang tepat dan terarah (Syam- 
Tabel 1. Jumlah Rumah Tangga, Desa, Rumah Tangga Miskin, dan Desa Tertinggal di Kabupaten Kepulauan Meranti Tahun 2009

\begin{tabular}{cccccccc}
\hline \multirow{2}{*}{ No } & \multirow{2}{*}{ Kecamatan } & Rumah & Jumlah & \multicolumn{2}{c}{ Rumah tangga Miskin } & \multicolumn{2}{c}{ Desa Tertinggal } \\
\cline { 6 - 8 } & & Tangga & Desa & & Miskin & \% & \multicolumn{2}{c}{ Desa } & \% \\
\hline 1 & Tebing Tinggi & 17.745 & 16 & 4.953 & 27,91 & 10 & 62,50 \\
2 & Tebing Tinggi Barat & 3.585 & 8 & 1.598 & 44,57 & 6 & 75,00 \\
3 & Rangsang & 6.729 & 13 & 2.843 & 42,25 & 11 & 84,62 \\
4 & Rangsang Barat & 6.608 & 15 & 2.307 & 34,91 & 14 & 93,33 \\
5 & Merbau & 10.897 & 21 & 4.175 & 38,31 & 18 & 85,71 \\
& Jumlah & 45.564 & 73 & 15.876 & 34,84 & 59 & 80,82 \\
\hline
\end{tabular}

Catatan: Data sebelum pemekaran kecamatan

Sumber: Bappeda Kabupaten Kepulauan Meranti, 2010.

suar, 2010).

Berdasarkan data dari Pemerintah Daerah Kabupaten Kepulauan Meranti (Tabel 1) di daerah tersebut terdapat 73 desa. Sebagian besar dari desa yang ada yakni sebanyak 59 desa ( 80,82 persen) merupakan desa tertinggal. Jumlah rumah tangga sebanyak $45.564 \mathrm{KK}$, dan sebesar 34,84 persen (15.876 KK) merupakan rumah tangga miskin. Banyaknya desa tertinggal dan keluarga prasejahtera di daerah ini merupakan indikasi bahwa pembangunan ekonomi selama ini (semasa bergabung dengan kabupaten induk) belum menyentuh rakyat lapisan bawah sehingga dengan adanya krisis menyebabkan daerah-daerah pedesaan yang terpencil menjadi rentan sehingga terpuruk menjadi daerah miskin. Hal ini disebabkan selain oleh karena kebijaksanan yang salah dan distortif pada masa lalu juga karena kondisi wilayah Kabupaten Kepulauan Meranti merupakan wilayah pesisir.

Tantangan yang dihadapi oleh Kabupaten Kepulauan Meranti sebagai daerah otonom baru adalah peningkatan pembangunan daerah dan kemandirian dalam pembangunan tersebut. Pelaksana kebijakan di daerah harus dapat meningkatkan kesejahteraan rakyat melalui pembangunan yang merata dan berimbang di setiap kecamatan. Dengan kondisi dan potensi yang ada, maka diperlukan suatu kebijakan yang dapat mendorong pertumbuhan dan percepatan ekonomi di kabupaten kepulauan Meranti dengan tingkat kesejangan yang minimal.

Posisi Kabupaten Kepulauan Meranti yang sangat menguntungkan dari segi hinterland KEK Batam, maka ketimpangan dan kesenjang- an ekonomi di daerah dapat dikurangi dengan memacu pertumbuhan ekonomi melalui pengembangan potensi yang ada. Salah satu cara untuk mengatasi kesenjangan ini adalah dengan program pembangunan ekonomi untuk memberdayakan masyarakat pedesaan. Sesuai dengan ketersediaan sumberdaya alam dan sumberdaya manusia yang ada di pedesaan maka program pembangunan ekonomi yang cocok adalah pembangunan ekonomi yang berbasis sumberdaya pertanian pedesaan dan tidak membutuhkan tenaga kerja yang terampil dan berpendidikan tinggi. Program ini dapat berbentuk pembangunan pertanian tanaman perkebunan, tanaman makanan dan hortikultura serta perikanan.

Apabila diamati pembangunan di daerah Riau yang terjadi selama ini, adalah polarization effect, seperti terjadinya urbanisasi oleh tenaga kerja pedesaan, pemusatan industri pengolahan di daerah perkotaan. Sementara spread effect serta strikling down effect yang diharapkan malah tidak terjadi, seperti tidak berminatnya investor melakukan investasi di daerah pedesaan (sumber bahan baku). Akibat yang dirasakan adalah daerah yang sudah berkembang semakin berkembang dan di daerah tersebut akan terjadi penumpukan kegiatan industri, sementara daerah-daerah lain semakin tertinggal dan kurang diminati oleh investor (Syahza, 2007a).

Menurut Syahza (2007b), pembangunan pedesaan harus dilakukan dengan pendekatan yang sesuai dengan sifat dan cirinya. Pembangunan pedesaan harus mengikuti empat upaya besar, satu sama lain saling berkaitan dan merupakan strategi pokok pembangunan pede- 
saan, yaitu: Pertama, memberdayakan ekonomi masyarakat desa. Dalam upaya ini diperlukan masukan modal dan bimbingan-bimbingan pemanfaatan teknologi dan pemasaran untuk memampukan dan memandirikan masyarakat desa; Kedua, meningkatkan kualitas sumberdaya manusia pedesaan agar memiliki dasar yang memadai untuk meningkatkan dan memperkuat produktivitas dan daya saing; Ketiga, pembangunan prasarana di pedesaan. Untuk daerah pedesaan prasarana perhubungan merupakan kebutuhan yang mutlak, karena prasarana perhubungan akan memacu ketertinggalan masyarakat pedesaan; dan keempat, membangun kelembagaan pedesaan baik yang bersifat formal maupun nonformal. Kelembagaan yang dibutuhkan oleh pedesaan adalah terciptanya pelayanan yang baik terutama untuk memacu perekonomian pedesaan seperti lembaga keuangan.

Dari sisi lain tentang penyebab kesenjangan ekonomi menurut Alim (2007) menilai di dalam negeri kebijakan-kebijakan pemerintah lebih mengutamakan kepentingan pemodal industri di kota-kota ketimbang rakyat pedesaan. Di tingkat desa, pemerintah lebih banyak menerapkan kebijakan yang menguntungkan sebagian kecil elit desa daripada sebagian besar buruh tani. Contohnya adalah proyek intensifikasi pertanian yang menghasilkan hasil tani melimpah. Teknologi dan tatacara bertani dimoderenkan. Petani bisa panen dua-tiga kali setahun. Banyak petani berangkat haji. Ilmuwan menyebutnya revolusi hijau.

Dari uraian yang dikemukakan, maka penelitian ini diharapkan dapat menemukan model pengembangan daerah tertinggal dalam upaya percepatam pembangunan ekonomi pedesaan di Kabupaten Kepulauan Meranti provinsi Riau. Hasil penelitian ini diharapkan dapat sebagai masukan kepada Pemerintah Kabupaten Kepulauan Meranti dalam upaya membangun kabupaten yang mandiri.

Berkaitan dengan penelitian ini, beberapa pertanyaan berikut dapat dijadikan acuan dalam menyusun perumusan model pengembangan daerah tertinggal dalam upaya percepatan pembangunan ekonomi pedesaan di Kabupaten Kepulauan Meranti provinsi Riau, yaitu: 1) Kendala apa yang dihadapi dalam pengembangan potensi ekonomi di pedesaan; 2) Bagaimanakah perumusan model pengembangan daerah tertinggal dalam upaya percepatan pembangunan ekonomi pedesaan di Kabupaten Kepulauan Meranti. Penelitian ini secara umum bertujuan untuk menyusun rencana strategis model pengembangan daerah tertinggal dalam upaya percepatam pembangunan ekonomi pedesaan di Kabupaten Kepulauan Meranti.

\section{METODE PENELITIAN}

Penelitian ini dilakukan melalui survey dengan metode perkembangan (Developmental Research). Guna mendapatkan informasi secara umum tentang keadaan daerah-daerah yang potensial untuk dikembangkan, maka penelitian ini banyak memanfaatkan data primer yang didapatkan melalui survei. Data sekunder hanya bersifat sebagai pendukung.

Studi ini dilakukan di daerah Kabupaten Kepulauan Meranti provinsi Riau dengan pemilihan lokasi dilakukan secara cluster di daerah pedesaan dengan pertimbangan jumlah desa tertinggal, keluarga miskin dan jumlah penduduk per kecamatan. Untuk setiap lokasi desa yang terpilih, pengambilan sampel masyarakat miskin digunakan teknik pengumpulan data dengan metode purposive sampling. Metode ini digunakan dengan pertimbangan bahwa letak lokasi penelitian yang berpencaran, karakteristik masyarakat sebagai objek penelitian yang beragam, dan informasi yang diperlukan dapat diperoleh melalui kuesioner dan wawancara secara mendalam.

Variabel yang diukur dalam studi ini adalah variabel yang diperlukan untuk pembangunan desa tertinggal yang meliputi kelayakan teknis dan kelayakan berkembang di masa depan. Untuk mengetahui kedua kelayakan tersebut maka diperlukan data-data yang dapat memberikan informasi dalam studi ini, antara lain: 1) Data wilayah yang mempunyai indikasi potensial untuk pengembangan dan rencana lintas sektoral; 2) Data Ekonomi Wilayah; dan 3) Data Sosial dan Kependudukan.

Penelitian ini memerlukan data primer. Untuk data primer pengumpulan data dilaku- 
kan dengan metode Rapid Rural Appraisal (RRA), yaitu suatu pendekatan partisipatif untuk mendapatkan data/informasi dan penilaian (assesment) secara umum di lapangan dalam waktu yang relatif pendek. Kelebihan pendekatan ini adalah penelitian bisa mencakup daerah yang lebih luas dalam waktu relatif singkat untuk mendapatkan informasi yang luas secara umum. Pengumpulan informasi dan data dilakukan secara fleksibel, tidak terikat secara kaku dengan kuesioner. Dalam metode RRA ini informasi yang dikumpulkan terbatas pada informasi dan yang dibutuhkan sesuai dengan tujuan penelitian, namun dilakukan dengan lebih mendalam dengan menelusuri sumber informasi sehingga didapatkan informasi yang lengkap tentang sesuatu hal. Kuesioner berperan sebagai pedoman umum untuk mengingatkan peneliti agar tidak menyimpang dari tujuan penelitian.

Kekhususan lain dari RRA ini adalah survei pengumpulan informasi dilakukan oleh peneliti yang multidisipliner atau peneliti yang mampu melihat masalah secara multidisipliner. Untuk mengurangi penyimpangan (bias) yang disebabkan oleh unsur subjektif peneliti maka setiap kali selesai melakukan interview dengan responden dilakukan diskusi di antara peneliti, saling tukar informasi tentang suatu masalah tertentu. Kalau ditemui perbedaan pandangan dalam suatu masalah yang disebabkan oleh adanya informasi yang keliru atau salah interpretasi maka dilakukan konfirmasi terhadap sumber informasi atau dicari informasi tambahan sehingga akan didapatkan persepsi yang sama diantara peneliti.

Data yang telah dikumpulkan dilanjutkan dengan pentabulasian sesuai dengan kebutuhan studi kemudian dilanjutkan dengan penganalisaan secara deskriptif. Di samping itu juga dilakukan analisis kuantitatif melalui pendekatan konsep pengembangan tata ruang wilayah ditinjau dari berbagai aspek, serta disesuaikan dengan keadaan fisik, ekonomi, kebijakan pemerintah, daya dukung lahan, serta sosial budaya masyarakat.

Penelitian ini merupakan kajian menemukan Strategi Pengembangan Daerah Tertinggal dalam Upaya Percepatam Pembangunan Ekonomi Pedesaan di Kabupaten Kepulauan Me- ranti. Sasaran yang hendak dicapai adalah memacu pertumbuhan dan percepatan pembangunan di daerah tertinggal dengan sasaran peningkatan taraf hidup masyarakat desa tertinggal. Untuk itu perlu diinvertarisir sumberdaya yang berpotensi untuk dikembangkan dari si ekonomi, sosial dan budaya masyarakat tempatan.

Analisis data dilakukan secara deskriptif kuantitatif dan kualitatif melalui pendekatan konsep ekonomi kerakyatan dari berbagai aspek, serta disesuaikan dengan keadaan fisik, ekonomi, dan kebijakan pemerintah.

\section{HASIL DAN PEMBAHASAN}

Dalam memacu pertumbuhan ekonomi, kebijaksanaan ekonomi harus menganut paradigma baru dimana pemberdayaan ekonomi rakyat harus menjadi perhatian utama. Karena sebagian besar di daerah pedesaan rakyat hidup pada sektor pertanian dan sektor ini masih memberikan kontribusi yang besar pada perekonomian daerah, maka pemberdayaan ekonomi rakyat juga berarti membangun ekonomi pedesaan dengan lebih baik. Pembangunan industri harus memperhatikan keterkaitan kebelakang (backward linkage) dengan sektor pertanian atau sektor primer sedangkan keterkaitan kedepan (forward lingkage) harus memperhatikan pengolahan untuk meningkatkan nilai tambah dan pemasaran yang baik sehingga produk yang dihasilkan tidak sia-sia.

Pengembangan sektor pertanian di pedesaan harus diarahkan kepada sistem agribisnis, karena pendekatan ini akan dapat meningkatkan nilai tambah sektor pertanian. Pada hakekatnya dapat meningkatkan pendapatan bagi pelaku-pelaku agribisnis di daerah. Sektor pertanian (agribisnis) sebagai sektor ekonomi rakyat di pedesaan memiliki prospek yang cerah untuk dikembangkan lebih lanjut, baik untuk memperkuat ekonomi rakyat, maupun sebagai andalan Indonesia dalam perdagangan bebas. Ketimpangan pembangunan pada masa lalu lebih memihak kepada sektor ekonomi perkotaan yaitu industri dan jasa, sementara ekonomi pedesaan yakni pertanian terabaikan. Tidak bisa dipungkiri, sejak krisis ekonomi 
tahun 1998 sektor pertanian memperlihatkan perubahan ekonomi di pedesaan menjadi lebih baik karena ditopang oleh komoditas yang berorientasi ekspor.

Pembangunan ke depan tidak bisa meremehkan pembangunan pedesaan melalui pengembangan sektor pertanian. Hal tersebut disebabkan sektor pertanian mempunyai peluang untuk dikembangkan di masa datang, antara lain: 1) Penduduk yang semakin bertambah sehingga kebutuhan pangan juga bertambah, ini merupakan peluang pasar yang baik bagi pelaku agribisnis; 2) Meningkatnya pendapatan masyarakat akan meningkatkan kebutuhan pangan berkualitas dan beragam (diversifikasi). Keragaman produk menuntut adanya pengolahan hasil (agroindustri); dan 3) Perkembangan agribisnis juga akan berdampak terhadap pertumbuhan ekonomi suatu daerah, meningkatkan pendapatan petani yang pada akhirnya diharapkan akan mengurangi ketimpangan pendapatan masyarakat.

Harapan masa depan sektor pertanian tersebut tidak bisa diraih dengan begitu mudahnya. Keberhasilan sektor pertanian juga tidak lepas dari peran pemerintah sebagai pembuat kebijakan, perusahaan agribisnis sebagai investasi dan penggerak pasar, dan partisipasi masyarakat tani untuk meningkatkan kuantitas dan kualitas produknya. Selain dari ketiga komponen tersebut, di lapangan ditemukan kendala yang dihadapi oleh pelaku usahatani berupa adanya mafia pemasaran produk pertanian. Apakah produk usahatani skala kecil maupun skala besar. Pada skala kecil di pedesaan ditemukan mafia pemasaran hasil pertanian yang dilakukan oleh pedagang pengumpul (istilah pedesaan toke) tingkat desa maupun di tingkat kecamatan. Mereka ini mempunyai kekuatan untuk mengendalikan harga di tingkat petani dengan berbagai dalih/ alasan. Sementara di tingkat skala besar bentuk mafia pemasaran lebih penekanan kepada kekuatan modal dan kekuasaan pasar dan kartel produk pertanian.

\section{Gambaran Daerah dan Kondisi Penduduk di Lokasi Penelitian}

Wilayah Kabupaten Kepulauan Meranti memiliki luas 369.807 Ha (daratan), 320.606 Ha (laut).
Total luas wilayah 680.413 Ha. Batas wilayah administrasi Kabupaten Kepulauan Meranti: sebelah Utara dengan Kabupaten Bengkalis dan Selat Malaka; sebelah Selatan dengan Kabupaten Siak dan Kabupaten Pelalawan; sebelah Timur dengan Kabupaten Karimun (Provinsi Kepulauan Riau); sebelah Barat dengan Kabupaten Bengkalis dan Kabupaten Siak. Kabupaten Kepulauan Meranti (setelah pemekaran) terdiri dari 7 Kecamatan dengan 73 desa dan kelurahan yang berada di 4 pulau utama (Pulau Padang, Merbau, Rangsang dan Tebing Tinggi). Penduduk Kabupaten Kepulauan Meranti tahun 2010 berjumlah 230.007,7 jiwa dengan kepadatan rata-rata sekitar 64 jiwa/Ha.

Berdasarkan data yang diperoleh dari Badan Perencanaan Pembangunan Daerah Kabupaten Kepulauan Meranti (2010), tingkat kemiskinan di Kabupaten Kepulauan Meranti mencapai 42,5 persen. Kemiskinan ini diatas kemiskinan tingkat provinsi Riau, bahkan sangat tinggi dibandingkan tingkat kemiskinan nasional yakni sebesar 13,13 persen. Perbandingan tingkat kemiskinan masyarakat Kabupaten Kepulauan Meranti dengan provinsi dan nasional disajikan pada Gambar 1. Tingginya tingkat kemiskinan di Kabupaten Kepulauan Meranti lebih banyak disebabkan daerah tertinggal. Daerah tersebut terpencar di wilayah pesisir dan terbatasnya sarana dan prasara terutama akses transportasi.

\section{Kendala dalam Pembangunan Ekonomi di Pedesaan}

Pembangunan ekonomi pedesaan terutama di daerah yang terpencil (tertinggal) tidak terlepas dari pembangunan sektor pertanian. Kondisi ini disebabkan karena sebagian besar masyarakat pedesaan (sekitar 80 persen) mencari nafkah dari sektor pertanian yakni: perkebunan, perikanan, peternakan, kehutanan, tanaman pangan dan hortikultura. Apabila ingin memacu pertumbuhan ekonomi di pedesaan salah satu prioritasnya adalah pengembangan sektor pertanian yang berbasis agribisnis. Untuk jenis agribisnis skala besar seperti perkebunan boleh dikatakan tidak banyak kendala, karena sektor perkebunan yang dikembangkan selama ini berorientasi ekspor yang dikelola oleh perusahaan besar. Namun yang jadi masalah adalah 


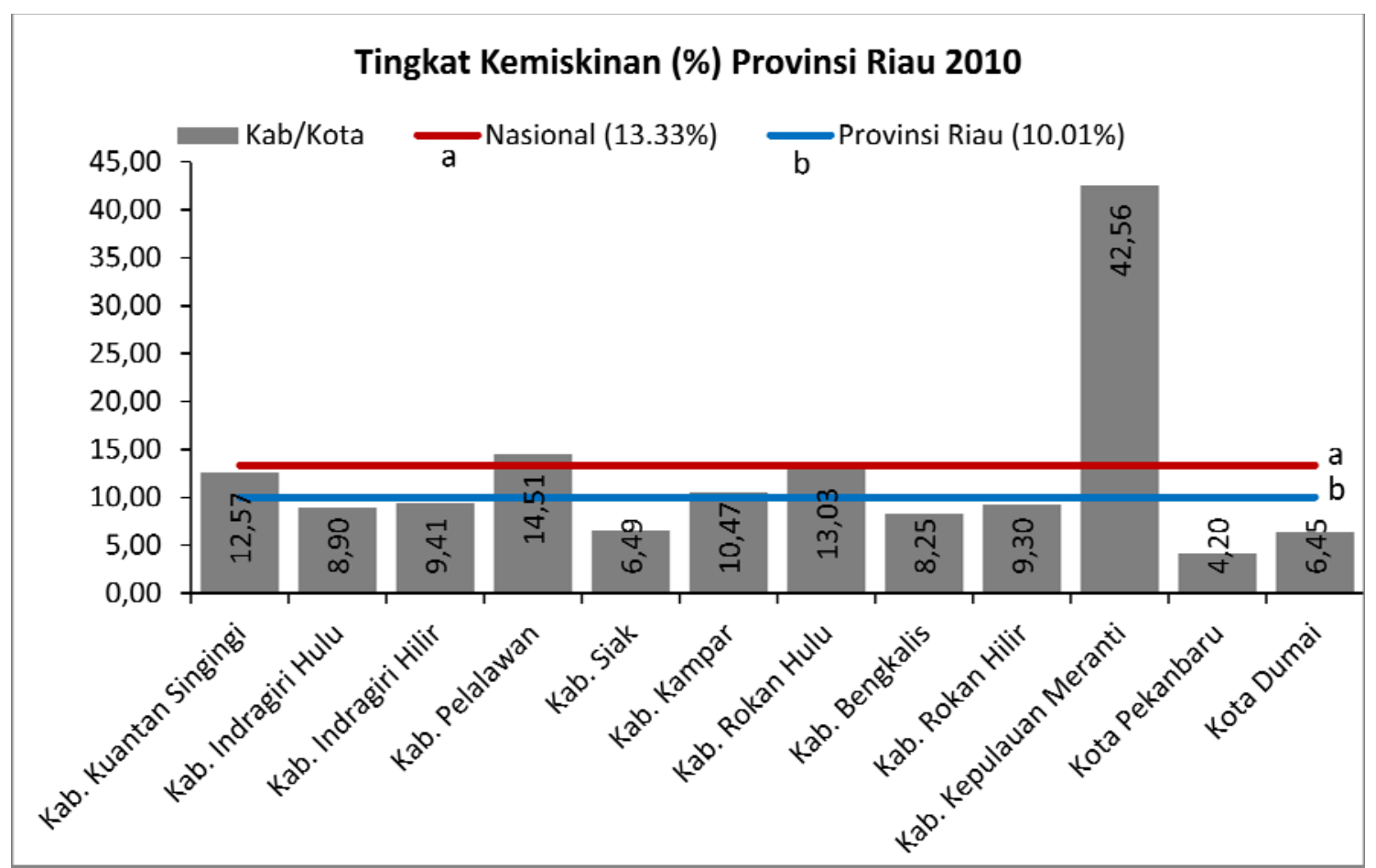

Sumber: Bappeda Kabupaten Kepulauan Meranti, 2010

Gambar 1. Perbandingan Tingkat Kemiskinan Antar Kabupaten-Kota di Propinsi Riau dan Nasional

pengembangan ekonomi pedesaan dari usahatani skala kecil yang dikelola secara swadaya oleh masyarakat.

Dalam pengembangan sektor pertanian skala kecil tersebut masih ditemui beberapa kendala, terutama dalam pengembangan sistem pertanian yang berbasiskan agribisnis dan agroindustri. Kendala yang dihadapi dalam pengembangan pertanian khususnya petani skala kecil, antara lain: Pertama, lemahnya struktur permodalan dan akses terhadap sumber permodalan. Salah satu faktor produksi penting dalam usaha tani adalah modal. Besar-kecilnya skala usaha yang dilakukan tergantung dari pemilikan modal. Secara umum pemilikan modal bagi masyarakat pedesan masih relatif kecil, karena modal ini biasanya bersumber dari penyisihan pendapatan usaha sebelumnya. Untuk memodali usaha selanjutnya masyarakat desa (petani) terpaksa memilih alternatif lain, yaitu meminjam uang pada orang lain yang lebih mampu (pedagang) atau segala kebutuhan usaha tani diambil dulu dari toko dengan perjanjian pembayarannya setelah panen. Kondisi seperti inilah yang menyebabkan petani sering terjerat pada sistem pinjaman yang seca- ra ekonomi merugikan pihak petani.

Kedua, ketersediaan lahan dan masalah kesuburan tanah. Kesuburan tanah si pedesaan sebagai faktor produksi utama dalam pertanian makin bermasalah. Permasalahannya bukan saja menyangkut makin terbatasnya lahan yang dapat dimanfaatkan petani, tetapi juga berkaitan dengan perubahan perilaku petani dalam berusaha tani. Dari sisi lain mengakibatkan terjadinya pembagian penggunaan tanah untuk berbagai subsektor pertanian yang dikembangkan oleh petani.

Ketiga, pengadaan dan penyaluran sarana produksi. Sarana produksi sangat diperlukan dalam proses produksi untuk mendapatkan hasil yang memuaskan. Pengadaan sarana produksi di pedesaan itu bukan hanya menyangkut ketersediaannya dalam jumlah yang cukup, tetapi yang lebih penting adalah jenis dan kualitasnya. Oleh karena itu pengadaan sarana produksi ini perlu direncanakan sedemikian rupa agar dapat dimanfaatkan sesuai dengan kebutuhan dan dipergunakan pada waktu yang tepat.

Keempat, terbatasnya kemampuan dalam penguasaan teknologi. Usaha pertanian di 
pedesaan merupakan suatu proses yang memerlukan jangka waktu tertentu. Dalam proses tersebut akan terakumulasi berbagai faktor produksi dan sarana produksi yang merupakan faktor masukan produksi yang diperlukan dalam proses tersebut untuk mendapatkan keluaran yang diinginkan. Petani yang bertindak sebagai manajer dan pekerja pada usaha taninya haruslah memiliki pengetahuan dan keterampilan dalam penggunaan berbagai faktor masukan usaha tani, sehingga mampu memberikan pengaruh terhadap peningkatan produktivitas dan efisiensi usaha yang dilakukan.

Kelima, lemahnya organisasi dan manajemen usaha tani. Organisasi merupakan wadah yang sangat penting dalam masyarakat, terutama kaitannya dengan penyampaian informasi (top down) dan panyaluran inspirasi (bottom up) para anggotanya. Dalam pertanian organisasi yang tidak kalah pentingnya adalah kelompok tani. Selama ini kelompok tani sudah terbukti menjadi wadah penggerak pengembangan pertanian di pedesaan. Hal ini dapat dilihat dari manfaat kelompok tani dalam hal memudahkan koordinasi, penyuluhan dan pemberian paket teknologi.

Keenam, kurangnya kuantitas dan kualitas sumberdaya manusia untuk sektor agribisnis. Petani merupakan sumberdaya manusia yang memegang peranan penting dalam menentukan keberhasilan suatu kegiatan usaha tani, karena petani merupakan pekerja dan sekaligus manajer dalam usaha tani itu sendiri. Ada dua hal yang dapat dilihat berkaitan dengan sumberdaya manusia ini, yaitu jumlah yang tersedia dan kualitas sumberdaya manusia itu sendiri. Kedua hal ini sering dijadikan sebagai indikator dalam menilai permasalahan yang ada pada kegiatan pertanian.

Secara umum permasalahan yang yang dihadapi dan harapan dalam pelaksanaan program kemiskinan bagi masyarakat pedesaan disajikan pada Tabel 2.

\section{Kendala dalam Pemasaran Produk Pertanian}

Pemasaran pertanian merupakan satu kesatuan urutan lembaga-lembaga pemasaran. Pemasaran bertujuan untuk memperlancar aliran produk pertanian dari produsen awal ke industri pengolah atau ke tangan konsumen akhir. Pemasaran produk pertanian mencakup banyak lembaga, baik yang berorientasi laba maupun nirlaba, baik yang terlibat dan terkait secara langsung maupun yang tidak terlibat atau terkait langsung dengan operasi sistem pemasaran pertanian. Khusus untuk beberapa komoditas terutama komoditas yang berorientasi ekspor seperti komoditas perkebunan

Tabel 2. Permasalahan dan Harapan pada Masyarakat Pedesaan

\begin{tabular}{|c|c|}
\hline Kondisi saat ini & Kondisi yang diharapkan \\
\hline 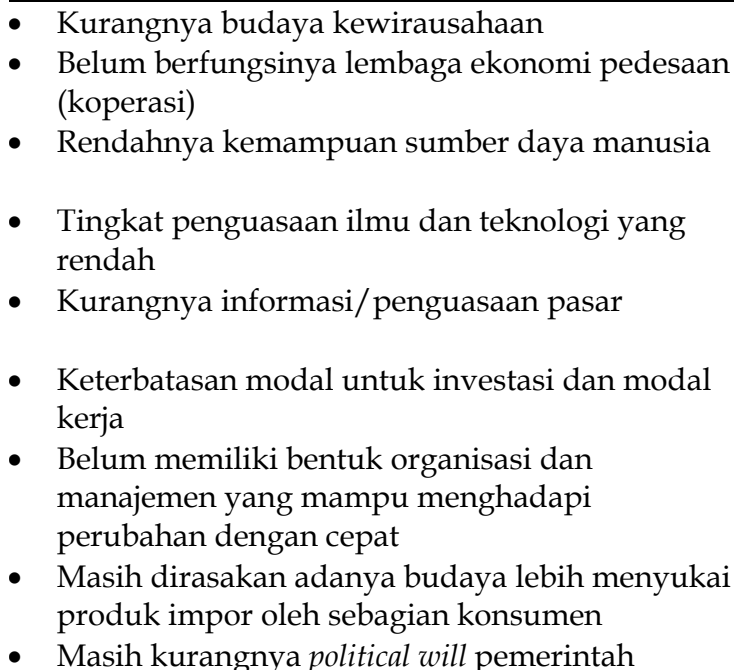 & 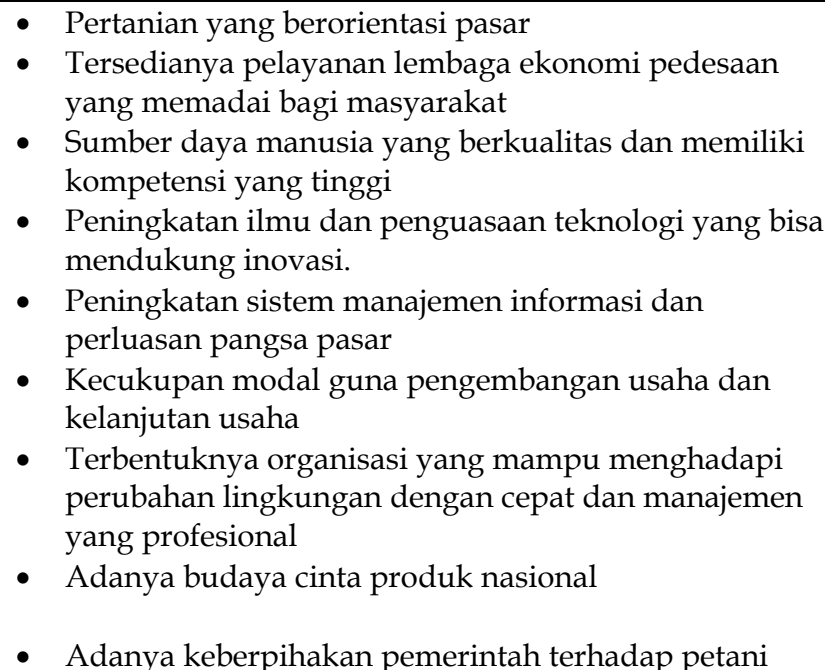 \\
\hline
\end{tabular}

Sumber: Almasdi Syahza (2009) 
(kelapa sawit, karet, kelapa, kakao, pinang, gambir, dan lain sebagainya) sering dihadapi dengan kendala pemasaran, terutama di daerah pedesaan. Bagi petani keterbatasan pengetahuan dan ketidakjelian pasar justru dimanfaatkan oleh pelaku-pelaku bisnis di daerah (yang dikenal dengan toke). Pelaku ini sering memanfaatkan kondisi di pedesaan untuk mempermainkan harga, sehingga pihak petani selalu berada pada posisi tawar menawar yang rendah. Bahkan dalam kondisi tertentu harga hanya ditentukan sepihak oleh para toke, akibatnya petani sebenarnya menghadapi pasar monopsonistic. Sebagai catatan toke adalah pedagang pengumpul hasil pertanian di pedesaan dengan memiliki bergagai fasilitas sarana dan prasarana serta modal yang kuat. Pada waktu tertentu petani diberi pinjamam uang untuk kebutuhan harian tanpa anggunan. Namun imbalannya adalah hasil pertanian harus dijual kepada toke. Pada kondisi ini si toke mempunyai kekuatan menawar dengan harga yang rendah. Dari sisi lain peluang si toke (kalau boleh disebut mafia pemasaran) memanfaatkan kelemahan pemasaran sektor pertanian di pedesaan.

Pemasaran dalam kegiatan pertanian dianggap memainkan peran ganda. Peran pertama merupakan peralihan harga antara produsen dengan konsumen. Peran kedua adalah transmisi fisik dari titik produksi (petani atau produsen) ke tempat pembelian (konsumen). Namun untuk memainkan kedua peran tersebut petani menghadapi berbagai kendala untuk memasarkan produk pertanian, khususnya bagi petani berskala kecil. Masalah utama yang menyebabkan harga dapat dipermainkan oleh mafia pemasaran adalah melalui titik lemah produk pertanian, antara lain:

(1) Kesinambungan produksi. Salah satu penyebab timbulnya berbagai masalah pemasaran hasil petanian berhubungan dengan sifat dan ciri khas produk pertanian, yaitu: Pertama, volume produksi yang kecil karena diusahakan dengan skala usaha kecil (small scale farming). Pada umumnya petani melakukan kegiatan usahatani dengan luas lahan yang sempit, yaitu kurang dari 0,5 ha. Di samping itu, teknologi yang digunakan masih sederhana dan belum dikelola secara intensif, sehingga produksinya belum optimal. Kedua, produksi bersifat musiman sehingga hanya tersedia pada waktu-waktu tertentu. Kondisi tersebut mengakibatkan pada saat musim produksi yang dihasilkan melimpah sehingga harga jual produk tersebut cenderung menurun. Sebaliknya pada saat tidak musim produk yang tersedia terbatas dan harga jual melambung tinggi, sehingga pedagangpedagang pengumpul harus menyediakan modal yang cukup besar untuk membeli produk tersebut. Bahkan pada saat-saat tertentu produk tersebut tidak tersedia sehingga perlu didatangkan dari daerah lain. Ketiga, lokasi usahatani yang terpencar-pencar sehingga menyulitkan dalam proses pengumpulan produksi. Hal ini disebabkan karena letak lokasi usahatani antara satu petani dengan petani lain berjauhan dan mereka selalu berusaha untuk mencari lokasi penanaman yang sesuai dengan keadaan tanah dan iklim yang cocok untuk tanaman yang diusahakan. Kondisi tersebut menyulitkan pedagang pengumpul dalam hal pengumpulan dan pengangkutan, sehingga membutuhkan waktu yang cukup lama untuk mengumpulkan produk yang dihasilkan petani. Kondisi tersebut akan memperbesar biaya pemasaran. Keempat, sifat produk pertanian yang mudah rusak, berat dan memerlukan banyak tempat. Hal ini menyebabkan ada pedagang-pedagang tertentu yang tidak mampu menjual produk pertanian, karena secara ekonomis lebih menguntungkan menjual produk industri (agroindustri). Ketidak senambungan produksi pertanian merupakan celah bagi mafia pemasaran di pedesaan, baik waktu membeli hasil pertanian maupun waktu menjual kebutuhan petani di pedesaan terutama kebutuhan harian sebagai pendukung aktifitas di pedesaan.

(2) Kurang memadainya pasar. Kurang memadainya pasar yang dimaksud berhubungan dengan cara penetapan harga dan pembayaran. Ada tiga cara penetapan harga jual produk pertanian yaitu: sesuai dengan harga yang berlaku; tawar-menawar; dan borongan. Pemasaran sesuai dengan harga yang berlaku tergantung pada penawaran dan permintaan yang mengikuti mekanisme pasar. Penetapan harga melalui tawar-menawar lebih bersifat kekeluargaan, apabila tercapai kesepakatan 
antara penjual dan pembeli maka transaksi terlaksana. Praktek pemasaran dengan cara borongan terjadi karena keadaan keuangan petani yang masih lemah. Cara ini terjadi melalui pedagang perantara. Pedagang perantara ini membeli produk dengan jalan memberikan uang muka kepada petani. Hal ini dilakukan sebagai jaminan terhadap produk yang diingini pedagang bersangkutan, sehingga petani tidak punya keberanian untuk menjualnya kepada pedagang lain, karena ada rasa tanggung jawab pada janji yang telah disepakati antara petani dengan pedagang bersangkutan.

(3) Panjangnya saluran pemasaran. Panjangnya saluran pemasaran menyebabkan besarnya biaya yang dikeluarkan (marjin pemasaran yang tinggi) serta ada bagian yang dikeluarkan sebagai keuntungan pedagang. Hal tersebut cenderung memperkecil bagian yang diterima petani dan memperbesar biaya yang dibayarkan konsumen. Panjang pendeknya saluran pemasaran ditandai dengan jumlah pedagang perantara yang harus dilalui mulai dari petani sampai ke konsumen akhir.

(4) Rendahnya kemampuan tawar-menawar. Kemampuan petani dalam penawaran produk yang dihasilkan masih terbatas karena keterbatasan modal yang dimiliki, sehingga ada kecenderungan produk-produk yang dihasilkan dijual dengan harga yang rendah. Berdasarkan keadaan tersebut, maka yang meraih keuntungan besar pada umumnya adalah pihak pedagang. Keterbatasan modal tersebut berhubungan dengan: Pertama, sikap mental petani yang suka mendapatkan pinjaman kepada tengkulak dan pedagang perantara. Hal ini menyebabkan tingkat ketergantungan petani yang tinggi pada pedagang perantara, sehingga petani selalu berada dalam posisi yang lemah; Kedua, fasilitas perkreditan yang disediakan pemerintah belum dapat dimanfaatkan secara optimal. Ada beberapa faktor yang menyebabkannya antara lain belum tahu tentang prosedur pinjaman, letak lembaga perkreditan yang jauh dari tempat tinggal, tidak mampu memenuhi persyaratan yang telah ditetapkan. Di samping itu khawatir terhadap risiko dan ketidakpastian selama proses produksi sehingga pada waktunya tidak mampu mengembalikan kredit. Ini menunjukkan pengetahuan dan pe- mahaman petani tentang masalah perkreditan masih terbatas, serta tingkat kepercayaan petani yang masih rendah.

(5) Berfluktuasinya harga. Harga produksi hasil pertanian yang selalu berfluktuasi tergantung dari perubahan yang terjadi pada permintaan dan penawaran. Naik turunnya harga dapat terjadi dalam jangka pendek yaitu per bulan, per minggu bahkan per hari atau dapat pula terjadi dalam jangka panjang.

Untuk komoditas pertanian yang cepat rusak seperti sayur-sayuran dan buah-buahan pengaruh perubahan permintaan pasar kadangkadang sangat menyolok sekali sehingga harga yang berlaku berubah dengan cepat. Hal ini dapat diamati perubahan harga pasar yang berbeda pada pagi, siang dan sore hari. Pada saat musim produk melimpah harga rendah, sebaliknya pada saat tidak musim harga meningkat drastis. Keadaan tersebut menyebabkan petani sulit dalam melakukan perencanaan produksi, begitu juga dengan pedagang sulit dalam memperkirakan permintaan.

(6) Kurang tersedianya informasi pasar. Informasi pasar merupakan faktor yang menentukan apa yang diproduksi, di mana, mengapa, bagaimana dan untuk siapa produk dijual dengan keuntungan terbaik. Oleh sebab itu informasi pasar yang tepat dapat mengurangi resiko usaha sehingga pedagang dapat beroperasi dengan margin pemasaran yang rendah dan memberikan keuntungan bagi pedagang itu sendiri, produsen dan konsumen. Keterbatasan informasi pasar terkait dengan letak lokasi usahatani yang terpencil, pengetahuan dan kemampuan dalam menganalisis data yang masih kurang dan lain sebagainya. Di samping itu, dengan pendidikan formal masyarakat khususnya petani masih sangat rendah menyebabkan kemampuan untuk mencerna atau menganalisis sumber informasi sangat terbatas. Kondisi tersebut menyebabkan usahatani dilakukan tanpa melalui perencanaan yang matang. Dari pihak pemasaran, justru memanfaatkan kondisi ini untuk menekan harga jual demi mendapatkan keuntungan yang besar.

(7) Kurang jelasnya jaringan pemasaran. Produsen dan/atau pedagang dari daerah sulit untuk menembus jaringan pemasaran yang ada di daerah lain karena pihak-pihak yang terlibat 
dalam jaringan pemasaran tersebut dan tempat kegiatan berlangsung tidak diketahui. Di samping itu, tidak diketahui pula aturan-aturan yang berlaku dalam sistem tersebut. Hal ini menyebabkan produksi yang dihasilkan mengalami hambatan dalam hal perluasan jaringan pemasaran. Pada umumnya suatu jaringan pemasaran yang ada antara produsen dan pedagang memiliki suatu kesepakatan yang membentuk suatu ikatan yang kuat. Kesepakatan tersebut merupakan suatu rahasia tidak tertulis yang sulit untuk diketahui oleh pihak lain.

(8) Rendahnya kualitas produksi. Rendahnya kualitas produk yang dihasilkan karena penanganan yang dilakukan belum intensif. Masalah mutu ini timbul karena penanganan kegiatan mulai dari pra panen sampai dengan panen yang belum dilakukan dengan baik. Masalah mutu produk yang dihasilkan juga ditentukan pada kegiatan pasca panen, seperti melalui standarisasi dan grading. Standarisasi dapat memperlancar proses muat-bongkar dan menghemat ruangan. Grading dapat menghilangkan keperluan inspeksi, memudahkan perbandingan harga, mengurangi praktek kecurangan, dan mempercepat terjadinya proses jual beli. Dengan demikian kedua kegiatan tersebut dapat melindungi barang dari kerusakan, di samping itu juga mengurangi biaya angkut dan biaya penyimpanan.

Namun demikian kedua kegiatan tersebut sulit dilakukan untuk produksi hasil pertanian yang cepat rusak. Kemungkinan-kemungkinan yang dapat terjadi antara lain mutu produk dapat berubah setelah berada di tempat tujuan, susut dan/atau rusak karena pengangkutan, penanganan dan penyimpanan. Hal ini menyebabkan produk yang sebelumnya telah diklasifikasikan berdasarkan mutu tertentu sesuai dengan permintaan dapat berubah sehingga dapat saja ditolak atau dibeli dengan harga yang lebih murah.

(9) Rendahnya kualitas sumberdaya manusia. Masalah pemasaran yang tak kalah pentingnya adalah rendahnya mutu sumberdaya manusia, khususnya di daerah pedesaan. Rendahnya kualitas sumberdaya manusia ini tidak pula didukung oleh fasilitas pelatihan yang memadai, sehingga penanganan produk mulai dari prapanen sampai ke pascapanen dan pemasaran tidak dilakukan dengan baik. Di samping itu, pembinaan petani selama ini lebih banyak kepada praktek budidaya dan belum mengarah kepada praktek pemasaran. Hal ini menyebabkan pengetahuan petani tentang pemasaran tetap saja kurang, sehingga subsistem pemasaran menjadi yang paling lemah dan perlu dibangun dalam sistem agribisnis.

Kondisi yang hampir sama juga terjadi di perkotaan, yaitu kemampuan para pedagang perantara juga masih terbatas. Hal ini dapat diamati dari kemampuan melakukan negosiasi dengan mitra dagang dan mitra usaha yang bertaraf modern (swalayan, supermarket, restoran, hotel) masih langka. Padahal pasar modern merupakan peluang produk pertanian yang sangat bagus karena memberikan nilai tambah yang tinggi.

Untuk mengatasi masalah pemasaran produk pertanian yang dialami oleh petani, maka perlu dipikirkan paradigma baru dalam mengatasi masalah tersebut. Terutama yang terkait dengan pemasaran produk pertanian. Salah satu alternatif pemecahannya adalah memberdayakan lembaga ekonomi pedesaan yaitu koperasi. Untuk memperkuat tawar menawar di tingkat petani, petani harus bersatu dalam satu wadah kepentingan bersama dalam bentuk organisasi ekonomi atau badan usaha di tingkat desa melalui kelompok-kelompok usaha seperti koperasi. Tanpa koperasi tidak mungkin agribisnis kecil dapat berkembang. Koperasi inilah yang akan berhubungan dengan pengusaha besar. Melalui koperasi masalah yang dihadapi oleh petani dapat teratasi.

Koperasi merupakan badan usaha di pedesaan dan pelaksana penuh subsistem agribisnis. Dari sisi lain koperasi juga merupakan pedagang perantara dari produk pertanian yang dihasilkan oleh anggotanya. Koperasi berfungsi sebagai lembaga pemasaran dari produk pertanian. Dalam koperasi dilakukan pengolahan hasil (sortiran, pengolahan, pengepakan, pemberian label, dan penyimpanan) sesuai dengan permintaan dan kebutuhan pasar. Koperasi juga berperan sebagai media informasi pasar, apakah menyangkut dengan peluang pasar, perkembangan harga, dan daya beli pasar. Melalui informasi pasar koperasi harus dapat 
menciptakan peluang pasar produk-produk pertanian, sehingga petani tidak ragu untuk melakukan kegiatan usahatani mereka karena ada jaminan dari koperasi bahwa produk mereka akan ditampung. Kegiatan ini akan merangsang partisipasi anggota terhadap koperasi, yang pada hakikatnya terjadi kesinambungan usaha koperasi.

Koperasi juga berperan sebagai penyedia kredit yang diperoleh dari lembaga perkreditan dan pengusaha. Pemberian kredit ini didasarkan kepada bentuk usaha pertanian yang mengembangkan komoditas unggulan dan punya peluang pasar. Tingkat pengembalian kredit oleh petani dapat dilakukan melalui pemotongan penjualan hasil pertanian kepada koperasi.

Kegiatan unit usaha ini akan menimbulkan multiplier effect ekonomi dalam kehidupan masyarakat. Pada hakikatnya usahata pertanian melalui sistem agribisnis sebagai unit usaha dapat menciptakan peluang usaha dalam kegiatan ekonomi sehingga menyebabkan naiknya pendapatan mayarakat yang pada akhirnya meningkatkan kesejahteraan masyarakat pedesaan. Melalui pembentukan koperasi agribisnis di pedesaan, maka mafia pemasaran di level bawah secara bertahap akan dapat dihilangkan.

\section{Program Pembangunan Daerah Tertinggal}

Sejalan dengan pengembangan ekonomi Indonesia yang bertumpu kepada ekonomi kerakyatan, maka pemerintah kabupaten/kota melakukan pembangunan ekonomi harus berbasis kerakyatan. Pembangunan ekonomi terutama di pedesaan dalam rangka mengangkat marwah, derajat, harkat, martabat masyarakat pedesaan sebagai upaya mewujudkan program pengetasan kemiskinan, meningkatkan kualitas sumberdaya manusia pedesaan dan pembangunan infrastruktur sebagai penunjang mobilitas barang dan penduduk desa-kota. Dalam upaya memacu pembangunan dari sisi aspek ekonomi dan sosial di daerah tertinggal, maka program pembangunan pedesaan harus memprioritaskan ketiga aspek tersebut.

(1) Peningkatan Ekonomi Rakyat (Mengentaskan Kemiskinan). Program kemiskinan merupakan pendekatan pembangunan yang bersifat komprehensif dan mendasar dalam tataran kesejahteraan dan harkat yang manusiawi, oleh karena sekalipun kemiskinan merupakan fenomena ekonomi namun memberikan konsekwensi yang kuat terhadap berbagai aspek kehidupan masyarakat sehingga mengakibatkan masyarakat yang mengalami kemiskinan tersebut menjadi rendah nilai-nilai kemanusiaannya sehingga dalam kehidupannya kurang bermarwah.

Khusus untuk daerah tertinggal pemilikan aset produktif seperti lahan sangat tidak adil, hal ini menyebabkan terjadi ketimpangan pendapatan bagi masyarakat pedesaan. Dari hasil pengamatan terlihat penguasaan asset produktif (lahan) di pedesaan lebih banyak dikuasai oleh perusahaan-perusahaan besar dan orang kota. Dampak dari semuanya ini terhadap mekanisme pasar yang dipengaruhi secara signifikan oleh aspek permodalan dan kebijakan yang kurang berpihak kepada masyarakat miskin. Masyarakat lebih banyak berhadapan dengan pasar yang bersifat monopsoni.

(2) Peningkatan Kualitas Sumberdaya Manusia (Pengetasan Kebodohan). Kebodohan sebagai cerminan dari rendahnya mutu sumberdaya manusia (SDM). Kualitas SDM sangat menentukan perubahan dan percepatan pembangunan disuatu daerah. Apabila kualitas SDM rendah, maka masyarakat akan sulit menerima perubahan, mereka tidak mampu untuk mengikuti perubahan baik dari sisi pembangunan maupun dari sisi kemajuan ekonomi. Mutu SDM yang rendah akan berdampak pada rendahnya tingkat keterampilan dan penguasaan teknologi. Individu ataupun kelompok masyarakat yang mengalami kondisi ini akan selalu menjadi objek pembangunan dan sangat terbatas kemampuannya untuk menjadi subjek yang berperan secara aktif dalam pembangunan.

(3) Pembangunan Infrastruktur. Pembangunan infrastruktur sangat diperlukan untuk melancarkan dan mensukseskan pencapaian berbagai tujuan dan keinginan di berbagai aspek kehidupan, terutama untuk mengentaskan kemiskinan dan mengatasi kebodohan. Pembangunan infrastruktur akan meningkatkan mobilitas manusia dan barang antardaerah dan antara kabupaten/kota. Peningkatan ini hendaknya tidak saja melalui kuantitas tetapi juga kualitasnya yang meliputi fasilitas 
transporlasi (jalan, jembatan, pelabuhan), fasilitas kelistrikan, fasilitas komunikasi, fasilitas pendidikan, dan fasilitas air bersih. Tersedianya infrastruktur yang memadai akan dapat mengembangkan potensi sumberdaya manusia (SDM) dan potensi sumberdaya alam (SDA) secara optimal dan dapat mengeliminasi kesenjangan antarkelompok masyarakat, antarwilayah kabupaten/kota, serta antara pedesaan dengan perkotaan. Semuanya ini akan semakin mengangkat derajat, harkat, martabat dan marwah rakyat di daerah pedesaan karena eksistensinya akan semakin diakui dan diperhitungan dalam konteks persaingan global.

\section{Kebijakan Pembangunan Daerah Tertinggal}

Pembinaan terhadap kelembagaan ekonomi masyarakat di daerah tertinggal, seperti koperasi, usaha kecil dan menengah serta usaha mikro lainnya, harus dikembangkan guna terwujudnya struktur perekonomian yang kuat dengan didukung oleh ekonomi rakyat yang tangguh. Untuk mendukung mengembangkan perekonomian daerah yang berbasis kerakyatan, dibutuhkan dukungan kebijakan dalam bentuk: 1) memberikan kepada masyarakat untuk berperan aktif dalam proses pembangunan dan pemberdayaan masyarakat, serta perubahan struktur masyarakat dengan pengembangan perencanaan pembangunan yang komprehensif/partisipatif, demokratis, aspiratif dan transparan; 2) melakukan restrukturisasi dan redistribusi kepemilikan asset produktif kepada masyarakat pedesaan dengan memakai standar skala ekonomi keluarga sejahtera (3 ha/KK); 3) melakukan optimalisasi peran dan fungsi seluruh perusahaan agribisnis dan forestry (dengan Peraturan Daerah) sebagai investor di pedesaan untuk melakukan reinvestasi melalui kemitraan pola perusahaan patungan bersama pemerintah dan masyarakat pedesaan dalam membangun sistem perekonomian pedesaan; 4) mengembangkan usaha kecil, menengah, koperasi dan usaha mikro lainnya dengan cara peningkatan dan pengembangan keterkaitan dan kemitraan usaha yang saling menguntungkan dan saling membutuhkan: 5) mengembangkan bidang-bidang yang mempunyai keterkaitan dengan pengembangan bidang-bidang lainnya yaitu bidang industri, pertanian dalam arti luas, bidang transportasi, perdagangan, pariwisata serta bidang kelautan yang cukup strategis sesuai dengan kondisi dan potensi yang dimiliki daerah; 6) meningkatkan upaya pembangunan infrastruktur terutama perhubungan darat, laut dan udara untuk meningkatkan aksesibilitas dan kelancaran lalu lintas orang dan barang; 7) mendorong upaya peningkatan nilai tambah (value added) sebagai produk pertanian yang dihasilkan oleh petani di pedesaan melalui sistem agribisnis dan agroindustri yang menekankan pada upaya pengembangan berbagai industri turunan; 8) memberdayakan lembaga dan organisasi ekonomi masyarakat di pedesaan sebagai wadah pengembangan kegiatan usaha produktif dan memberdayakan masyarakat miskin serta mendorong berkembangnya lembaga-lembaga keuangan mikro dalam rangka mendekatkan masyarakat pada akses permodalan guna mengembangkan ekonomi kerakyatan.

\section{SIMPULAN}

(1) Dalam memacu pertumbuhan ekonomi, kebijaksanaan ekonomi harus menganut paradigma baru dimana pemberdayaan ekonomi rakyat harus menjadi perhatian utama. Karena sebagian besar rakyat hidup pada sektor pertanian dan sektor ini masih memberikan kontribusi yang besar pada perekonomian negara, maka pemberdayaan ekonomi rakyat juga berarti membangun ekonomi pertanian dengan lebih baik.

(2) Pengembangan sektor pertanian ke depan harus diarahkan kepada sistem agribisnis, karena pendekatan ini akan dapat meningkatkan nilai tambah sektor pertanian. Pada hakekatnya dapat meningkatkan pendapatan bagi pelakupelaku agribisnis di daerah. Sektor pertanian (agribisnis) sebagai sektor ekonomi rakyat di pedesaan memiliki prospek yang cerah untuk dikembangkan lebih lanjut, baik untuk memperkuat ekonomi rakyat, maupun sebagai andalan Indonesia dalam perdagangan bebas.

(3) Sektor pertanian di kabupaten Kepulauan Meranti mempunyai peluang untuk dikembangkan di masa datang, antara lain: (a) Penduduk yang semakin bertambah sehingga kebu- 
tuhan pangan juga bertambah; (b) Meningkatnya pendapatan masyarakat akan meningkatkan kebutuhan pangan berkualitas dan beragam (diversifikasi); dan (c) Perkembangan agribisnis juga akan berdampak terhadap pertumbuhan ekonomi suatu daerah, meningkatkan pendapatan petani yang pada akhirnya diharapkan akan mengurangi ketimpangan pendapatan masyarakat.

(4) Dalam pengembangan sektor pertanian skala kecil masih ditemui beberapa kendala, terutama dalam pengembangan sistem pertanian yang berbasiskan agribisnis dan agroindustri. Kendala tersebut, antara lain: (a) lemahnya struktur permodalan dan akses terhadap sumber permodalan; (b) ketersediaan lahan dan masalah kesuburan tanah; (c) pengadaan dan penyaluran sarana produksi; (d) terbatasnya kemampuan dalam penguasaan teknologi; (e) lemahnya organisasi dan manajemen usaha tani; (f) kurangnya kuantitas dan kualitas sumberdaya manusia untuk sektor agribisnis.

(5) Dalam pemasaran produk pertanian di pedesaan, petani menghadapi berbagai kendala, khususnya bagi petani berskala kecil. Masalah utama yang menyebabkan harga dapat dipermainkan oleh mafia pemasaran adalah melalui titik lemah produk pertanian, antara lain: (a) kesinambungan produksi; (b) kurang memadainya pasar; (c) panjangnya saluran pemasaran; (d) rendahnya kemampuan tawar-menawar; (e) berfluktuasinya harga; (f) kurang tersedianya informasi pasar; (g) kurang jelasnya jaringan pemasaran; (h) rendahnya kualitas produksi; dan (i) rendahnya kualitas sumberdaya manusia.

\section{DAFTAR PUSTAKA}

Alim, Muhammad Kholikul. 2007. Negara Vs. Kemiskinan di Pedesaan,

http://uploadoverload.blogs.friendster. com/my_blog/2007/07/negara_vs_kemi s.html, 10 Agustus 2007.

Bappeda. 2010. Data Statistik Otonomi Daerah Kabupaten Kepulauan Meranti, Pemda kabupaten Kepulauan Meranti. Selat Panjang: Bappeda.
Richardson. 2001. Dasar-dasar Ilmu Ekonomi Regional. terjemahan Paul Sitohang. Jakarta: Penerbit FE-UI.

Syahza, Almasdi. 2007a. Model Pemberdayaan Masyarakat dalam Upaya Percepatan Pembangunan Ekonomi Pedesaan Berbasis Agribisnis di Daerah Riau. Penelitian Fundamental DP2M. Jakarta: Direktorat Jenderal Pendidikan Tinggi Departemen Pendidikan Nasional.

Syahza, Almasdi., 2007b. Percepatan Pemberdayaan Ekonmomi Masyarakat Pedesaan dengan Model Agroestate Berbasis Kelapa Sawit, dalam Jurnal Ekonomi, Th.XII/ 02/Juli/2007. Jakarta: PPD\&I Fakultas Ekonomi Universitas Tarumanagara.

Syahza, Almasdi. 2008. Percepatan Pembangunan Ekonomi Pedesaan Melalui Pemberdayaan Koperasi Berbasis Agribisnis di Daerah Riau. Penelitian Fundamental DP2M. Jakarta: Direktorat Jenderal Pendidikan Tinggi Departemen Pendidikan Nasional,

Syahza, Almasdi. 2009. Kelapa Sawit, Dampaknya terhadap Percepatan Pembangunan Ekonomi Pedesaan di Daerah Riau. Penelitian Hibah Kompetensi (tahun Pertama) DP2M. Jakarta: Direktorat Jenderal Pendidikan Tinggi Departemen Pendidikan Nasional.

Syamsuar. 2010. Harapan Masyarakat Kabupaten Kepulauan Meranti dalam Mewujudkan Otonomi Daerah. Makalah pada seminar: Peluang dan Tantangan Kabupaten Meranti dalam Mewujudkan Otonomi Daerah. Riau, Pekanbaru: Balitbangda Provinsi.

Zainal, Rusli. 2010. Menciptakan Kabupaten Kepulauan Meranti Sebagai Hinterland Free Trade Zone Batam. Makalah pada seminar: Peluang dan Tantangan Kabupaten Meranti dalam Mewujudkan Otonomi Daerah. Riau, Pekanbaru: Balitbangda Provinsi. 